\title{
Joachim Kügler
}

\section{THE (POSSIBLE) FUNCTION OF THE BEATITUDE OF THE POOR IN THE CONTEXT OF THE STRUGGLE AGAINST POVERTY}

\begin{abstract}
The article focuses on the beatitude of the poor in the social and religious context of historical Jesus. The original version of this makarism has to be seen as a religious statement which is not meant as a program of social reform. Yet it has political and socio-ethical implications as it connects the poor with God and his kingdom. Those who are searching God have to go to the poor. A possible function of the beatitude of the poor in the struggle against poverty can be seen in the spiritual empowerment it gives to the poor themselves: Poverty is against God's will; it is no divine punishment and does not separate from God. The poor will be liberated from suffering. Poverty has no place in the kingdom but will be eradicated.
\end{abstract}

\section{INTRODUCTION}

Without any doubt poverty is one of the most urgent problems in our time. It is an old problem and it is a quickly increasing one. While the ongoing process of economic globalization helps many people to improve their situation, it simultaneously increases the needs of many others. The gap between those who are well off and those who suffer is getting wider and wider, and additional threats like HIVIAIDS contribute to the "shadow of death" which many people are living in. This process can be seen in the Western countries, but is much more dramatic in the global South, i.e. in the countries of Africa, Asia and Latin America. South African Christians, as well as those in other countries, cannot ignore this severe problem, but have to understand it as a challenge of peace and justice. All of us

Joachim Kügler, University Bamberg, Germany. Guest lecturer, Department Missiology, University of the Free State. E-mail: joachim.kuegler@online.de

Acta Theologica

2012 Suppl 16: 1-16

DOI: http://dx.doi.org/10.4314/actat.v32i1S.1

ISSN 1015-8758

(C) UVIUFS

<http://www.uovs.ac.za/ActaTheologica> 
should understand that the struggle against poverty is part of our Christian mission. It is nothing that we choose to do (or not to do), but it is an essential of Christian life. As a Catholic scholar I may point to the texts of the Second Vatican Council, which defines the Christian Church as a kind of sacrament who was formed by God to preach and realize God's love to mankind. Being Church in itself means to serve those in need. And not serving those who suffer is equivalent to not being Church. Our faith in God's love and justice urges us to ask what we can do to share in solving the problem of poverty. As a biblical scholar I have to ask, what the tradition of the Bible can contribute to this struggle and how it might help in overcoming need and suffering. It is well known that the Old Testament has a lot to say on poverty and on the God's relation of the poor and oppressed. I will, however, focus here on the New Testament, especially on the oldest Jesus tradition, which leads us undoubtedly close to the core of our belief, to the Divine Word in person. The text to be analysed is the Beatitude of the Poor which forms a unity with two other beatitudes, namely those of the suffering and the mourning. Being part of the Sermon on the Mountain the beatitudes had great influence on the understanding of Christian life and can be seen as a key part of the teaching of Jesus. I will, however, in this article not deal with the traditional versions rendered by Matthew and Luke. Instead I try to go back beyond the final text of the Gospels and ask for the oldest form of the beatitudes. By that I join the broad tradition historical-critical research with its attempt to reconstruct the historical Jesus. The theological dignity of this attempt lies in the fact that according to oldest Christian tradition God does not reveal a text, but Himself, first in the history of Israel and then in Jesus Christ. Asking for the historical Jesus behind the text is thus a modern form of asking for God's self-revelation in history and, at the same time, acknowledging the Gospels as witnesses of this Divine revelation.

\section{IN SEARCH OF THE ORIGINAL WORDING}

When we ask, what Jesus really did and really said, there is always the same problem. The four gospels differ in rendering the words and deeds of our Lord. The main difference is between the Gospel of John and the three synoptic Gospels. This difference has lead to sorting out the Johannine Jesus story from the quest for the historical Jesus. Although many scholars see the chronology of Jesus' last days in Jerusalem more exactly given in the Johannine passion narrative, the rest of the Fourth Gospel mostly is seen as a theological narrative with high theological value, but without major relevance for historical questions. When it comes to the message of the historical Jesus usually only the synoptic gospels are seen as important 
sources. The Zwei-Quellen-Theorie, developed by German scholars in the $19^{\text {th }}$ century is still the standard theory for the relation between the Synoptics. This theory tells us that Mark is the oldest of the Synoptics and was used as a source by Luke and Matthew. The second source usually is detected where the text of Matthew and Luke goes together but differs from Mark. Since the times the Zwei-Quellen-Theorie originated, this second source, which helped Matthew and Luke to write their larger gospels, simply is called $Q$ or Sayings Source, in German: Logienquelle. Since some years we have the critical edition of the Logienquelle, which is the result of the analytical work of the International Q Project. ${ }^{1}$ When we now ask for the pre-synoptic wording of the Beatitudes we can easily follow the Greek text of the critical edition of $Q$, and I do so although the English translation rendered here is my own.

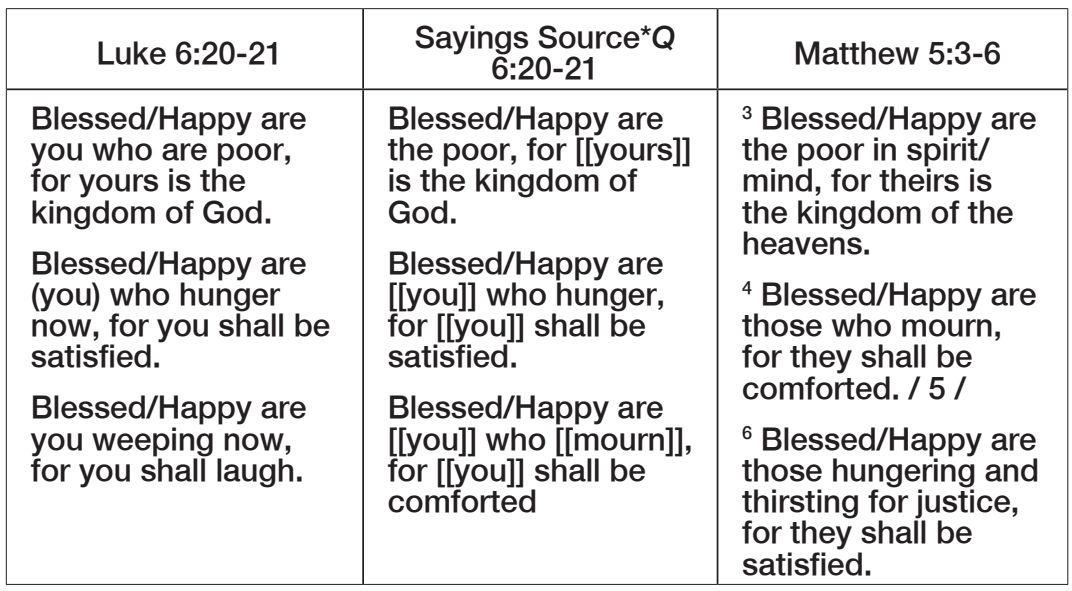

As can be easily seen from the synoptic reading and comparing the main points of difference between Luke and Matthew are:

- While Luke's version addresses simply those who are poor, Matthew is talking about those who are "poor in spirit", which usually is seen as an amendment.

1 This research program was headed by my predecessor at Bamberg University (and former supervisor) Paul Hoffmann, together with his colleagues James M. Robinson (USA) and John S. Kloppenborg (Canada). The results of the International Q Project's research were published in Robinson, Hoffmann \& Kloppenborg 2000. 
- The sequence of the beatitudes differs. While Luke has "poor - hungry - weeping" Matthew reads "poor - mourning - merciful - hungry". Usually priority is given to Luke's order and the beatitude of the merciful is seen as a redactional amendment by Matthew.

- Matthew defines the hungry ones as "hungering and thirsting for justice" which usually also is seen as his amendment.

- While in Luke the three beatitudes are addressing directly those who are meant, Matthew doesn't have the second person plural, but his beatitudes stand in the third person plural. It is very difficult to decide which form is more original. The text of the International Q Project leaves things open by using double brackets but perhaps one should prefer the third person plural for the reconstruction of a text prior to $Q$. My first argument is that this is the common form of a makarism in the OT and Early Judaism, although one has to admit that there are exceptions. ${ }^{2}$ Furthermore I would like to point out that the fourth beatitude, which usually is seen as an amendment of those who collected and redacted $Q$, stands in the second person plural. The fact that the $Q$ redactors chose this form of addressing directly to those who were suffering in the name of Christ makes it quite probable that the older beatitudes didn't have this direct addressing. Otherwise Matthew would have broken up a stylistic unity, which seems rather improbable to me. For him the four beatitudes already were a unit of Jesus tradition and there is no reason in sight why he should have changed just the last part of this unit.

In total I would therefore propose that the three oldest beatitudes which can be traced back to the time prior to the Logienquelle should have read like that:

Happy are the poor, for theirs is the Kingdom of God.

Happy are the hungering, for they shall be satisfied.

Happy are the weeping/mourning, for they shall be comforted. ${ }^{3}$

2 Collins states: "Of the 45 beatitudes in the Hebrew Bible, all but 4 (Deut 33:29; Ps 128:2; Qoh 10:17, in the 2nd person singular; and Isa 32:20, in the 2nd person plural) are in the 3rd person." (Collins 1992:629).

3 Cf. Meier 1994:323, who comes to a very similar reconstruction, with only changing the place of makarism 2 and 3 . 
We have to be rather careful not to mix up this (probable) version of the pre- $Q$ text with the original words of the historical Jesus. We may come close to Jesus with this text, but what I render here in English translation originally stands in Koine--Greek. As Jesus most probably used Aramaic for his teaching it is clear that we already are dealing with Jesus tradition jumping to the linguistic world of Hellenism. It may be a very early state of tradition, but it is tradition. When in the rest of this text I will talk about what Jesus did, said and meant, I do in now way claim to render Jesus' ipsissima vox, as Joachim Jeremias once called it. Instead, always when I say simply Jesus, I quite modestly refer to an early state of Jesus tradition merely, which may however come rather close to the historical Jesus. ${ }^{5}$

\section{SEMANTICS: THE MEANING OF WHAT JESUS SAID}

In my interpretation of Jesus' beatitude of the poor I will make a difference between sense and meaning of a text. ${ }^{6}$ In the perspective of linguistics the difference would meet up with the difference between the semantic and the pragmatic dimension of a text. While semantics has to do with what a text says philologically, pragmatics deals with the intended effect on the reader. This intended effect can be located in the realm of cognition, in the emotional sphere, in shaping attitudes and ethics or in stimulating direct action. Therefore pragmatics also has to do with the socio-religious context of a text and with its political relevance.

For a semantic understanding of the beatitude of the poor it is important to understand that the three makarisms ("poor - hungry weeping/mourning") form a unit. The first explains the second and the third beatitude. And the last two makarisms help understanding the first one. Based on this insight one can outline some important points:

- The three beatitudes contain no program of social revolution. Nobody is told to do something. The only "command" that can be detected is the impulse to be happy. Not only a socio-revolutionary interpretation

4 Read for example: "Zurück zur ipsissima vox Jesu, heißt die Aufgabe! Welch großes Geschenk, wenn es gelingt, hier und da hinter dem Schleier das Antlitz des Menschensohnes wiederzufinden! Erst die Begegnung mit Ihm gibt unserer Verkündigung Vollmacht!“ (Jeremias 1962:114).

5 Meier sees good arguments "for ascribing the core beatitudes of the Q Sermon to Jesus himself rather than to early Christians" (1994:330).

6 The differentiation between sense and meaning is based on the difference between Sinn and Bedeutung, which was developed in 1891 by the German philosopher Frege (2008). On the relevance of this difference for biblical theology cf. Sander 2005:61. 
is without semantic basis in the text, there is not even an outspoken incentive for social reform towards a more just society.

- The three beatitudes utter no ethical instruction for help. Jesus does not say that those who are well off should help those in need. His makarisms on a semantic level do not deal with charity.

- On the other side there is no affirmation of poverty as a religious ideal. If we leave away Matthews amendment "in the spirit/mind" and make clear the beatitude simply goes to the poor, it can easily be seen that the first makarism deals with poverty in a quite comprehensive way: absolute material poverty, mental and emotional deprivation as well as social marginalisation. And those suffering are not praised happy because their state of poverty, hunger and sadness would have any value in itself. They are praised as their suffering will be ended. ${ }^{7}$

- The first beatitude makes perfectly clear that we have to do with a religious statement. The reason why the poor should be happy is given with the "Kingdom of God" belonging to them. In the history of interpretation this expression was often understood as referring to a metaphysical, spiritual realm where the soul post mortem can meet God. This understanding was fostered by Matthew's wording "kingdom of the heavens" as well as by Luke's contrast between "now" and "then". That is why the common interpretation focussed on the contrast between being poor now, in this earthly life and being given the divine joy in the other, heavenly life. When we, however, look on the oldest wording, this interpretation has no basis anymore.

- As can be seen from the second and third makarism the first one clearly may be called a religious statement, but it definitely is no metaphysical statement. The reason why those suffering from hunger and sadness should be happy is given with "they shall be satisfied", respectively "be comforted". With these quite "earthly" expressions Jesus makes clear that his idea of Kingdom of God is not merely a spiritual or metaphysical one. His conception of the Kingdom of God derives from the OT and Early Jewish tradition and clearly means a certain state of the world where the salvific will of God is so absolutely realised that God really

7 For some Christian interpreters it may be kind of a problem to imagine that the poor share in the Kingdom of God without doing something for it. But as the Kingdom is exclusively God's action (cf. the 'automatically' in Mark 4: 28) the only thing one can 'do' is to believe in it. As far as the makarism is concerned the poor show their faith in the Kingdom of God simply by being happy. The makarism is not discussing the fate of those who are poor but do not believe in the God's help. 
can be called King in the fullest sense. One even can say that in the core of Jesus' basileía-teaching stands the process of God's taking power on earth. While "in heaven" God already is King - and always was, the life on earth is still to be subjected to God's royal command. Jesus sees this process as something that already has begun. The presence of God's Kingdom is realised already in certain situations and experiences, for example when people are delivered from evil powers: "But if I cast out demons by the finger of God, then the Kingdom of God has come upon you" (Luke 11:20). Through exorcism and healing, forgiving sin and reintegrating marginalized persons the basileía can be experienced. The Kingdom of God happens in these actions. So exorcism, healing, forgiving sin and eating with outcasts can be called happenings or sacramental realisations of God's Kingdom.

\section{THE SIGNIFICANCE (PRAGMATIC DIMENSION) OF THE BEATITUDE IN THE SOCIAL AND POLITICAL CONTEXT OF JESUS' TIME}

Often the pragmatic intention of a text is more important than the semantic one. If someone cries "Fire!!" when the house is burning, we shall not only understand that there is fire, but we are called to help and rescue this person. If we only understand the semantic information of this short text, we do not understand anything at all. In a certain way for Biblical texts also the pragmatic dimension is the most important one. Even those who do not give a direct instruction for acting try to do something with their readers. That is why it is so important to ask for the context of Biblical texts. It helps us not only to get an idea of what these texts wanted to do with their readers in the past, but also gives us some hints for their meaning nowadays.

When we look at ancient societies we usually see cultural systems which use religion as a power to legitimize the political and social order. God or the gods are seen as a power which stabilizes the political status quo. The powerful ruler is seen as the earthly representative of divine powers. That is why we have a lot of religious titles to express the theology of power surrounding Hellenistic kings as well as Roman emperors. The ruler is called "visible god", "son of god", "saviour", "god from god" and more (cf. Kügler 1997:133-173; and also Kügler 2006:5-10).

In the Jewish context some modifications of this basic religious structure were necessary due to the fact that one didn't have an own Jewish king since being occupied by the Romans. The official state theology 
surrounding the temple in Jerusalem propagated God as residing in the temple as his palace. This kind of "realized Kingdom of God theology" propagated by Jerusalem's priestly nobility traces back to Old Testament times. It can already be found in Isaiah's calling vision (Isa 6) and in many other texts also. It is rather sure that in pre-exilic times the religious status of the kings in Israel was the same as in pagan societies. In the time of Jesus, however, God was seen king residing in the temple without having an earthly king as counterpart and representative. De facto this role was played by the Roman emperor and his regional agents (like Herod and his successors), but this political reality could not be fully integrated into the state theology. ${ }^{8}$

Another conception of God's realized kingdom can be seen in the sapiential theology. Philo, philosophical theologian in Alexandria and member of Jewish upper class, conceives God as creator and supreme king of the universe, governing his creation through his eldest son, the divine word (logos). Although Philo never denies the value of the Jerusalem temple and its cult, the centre of his theology is wisdom. The best way of getting united with God is to open one's soul for the divine logos. Not very surprising for an ancient philosopher, Philo sees knowledge and insight as the privileged way to God. The wise man gets in touch with God by opening mind and soul for the divine word and thus becomes - by mediation of the logos -"son of God". ${ }^{9}$ Hailing the pagan Roman emperor as son of God is far away from Philo's thinking, but connecting the poor with the kingdom of God also is far away from him.

Exactly that is what Jesus did. He connected God with the poor and suffering. The Kingdom of God is promised to them, and it is promised to them without any condition. If we see Jesus' beatitude in the context of common political theology of his time it is quite clear that his connecting of God's kingdom and the poor is quite astonishing. The poor are powerless so why should they be connected with the supreme power of God? The emperor, rich and powerful is the normal representative of divine power. His reign is the realisation of the divine order. Jesus however ignores the common establishment theology of his time. He neither sees God and his kingdom much connected with the reign of a king or emperor nor does he connect the basileia with the wealthy upper class. The kingdom of God does not belong to those who dedicate to the temple and its cult, but to the poor.

8 The Jewish historian Josephus (Jewish War 6,312 f., and Antiquities 3,440-402) interpreted Vespasian (on his way to being emperor) as God's elected tool, but this in the time of Jesus remains quite exceptional, and even Josephus avoids messianic overtones in his theological interpretation of Vespasian's role. Cf. Kügler 1997:248-249.

9 For the role of the divine logos in Philo's writings cf. Tobin 1992:350-351. 
God's kingdom does not belong to those who can afford doing philosophy instead of working, but to the poor. By explicitly connecting God and the poor in an unconditioned makarism Jesus implicitly disconnects God and the upper class (emperor, high priests, rich and powerful families). The political, economical, and religious establishment seems out of sight when it comes to the Kingdom of God and to whom it belongs. ${ }^{10}$ Jesus obviously has no intention at all to legitimize and stabilize the status quo of ancient society. Just the opposite, his preaching derives from apocalyptic roots and can only be seen as a religious disenfranchisement of the political, social and religious conditions predominant in his world.

This theology of disenfranchisement has two key messages. One goes to the poor and is a message of spiritual empowerment. The poor are encouraged to understand themselves in a new way. They are not the worthless and powerless, ignored by God, scum of the earth, but they are those the kingdom of God belongs to. They are no quantité négligeable but are in the centre of God's attention in taking over control of his world. This spiritual empowerment of the poor is paralleled by a second message which goes to those who are seeking God. All those honestly seeking God and his kingdom are directed to the poor. They are told not to look for God in power or richness, not in the temple and not in the palace of the emperor. God is not with the powerful, noble and wealthy, but is to be found where the poor, the hungry and mourning are.

What Jesus does with his beatitude can be summed up as "switching the myth". Of course I use the word "myth" in a modern sense as it was developed in the last years by scholars like Jan Assmann and others (cf. e.g. Assmann 1992:75-78; Theissen 2000:21-23; Kügler 2003:311). While in antiquity "myth" was used to refer to something that is not true, mere fiction or even lie, the use of the word in cultural studies today refers to ideological frameworks predominant in cultural systems. In this perspective there is no culture without myth. Every culture develops its own mythical framework to make reality understandable, to order things, to give a meaning to life, and to tell us how we should behave, what we should do and think. In one of

10 This act of clearly disconnecting God and the upper class may seem too harsh, but it certainly is no over-interpretation of Jesus' beatitude of the poor. On the contrary this disconnecting undoubtedly is a part of the Jesus tradition as can be seen with Mark 10:25 and many other text. There is no reason to speculate that the critical view of richness might be construed only by post-Easter Christianity. It is much more probable that sayings and stories like Luke 6:24 or 16:19-31 although probably written later are following an original impulse given by the historical Jesus and his critical view of the precarious relation between rich people and the kingdom of God. This most probably is true even for late New Testament texts like 1.Timothy 2:9-10; 6:9 or James 5:1-6. 
my previous articles I tried to explain the Kingdom of God as the mythical framework (Rahmenmythos) of Jesus' mission, of his thinking and acting (cf. Kügler 2007). This myth is a counter-myth to the predominant religious and political order of his time. That is why Jesus calls his addressees to a new way of thinking. His call to metánoia is nothing less than adopting a new, salvific myth. In accordance to apocalyptic tradition people are invited to believe in a new myth. They shall no longer believe that the world is "okay" as it is. They have to switch the myth and understand that the status quo of the world is a state of sin, i.e. it is not according to God's will. God's basileía is something different, it is a new creation. For Jesus this new world already has begun and can be seen in experiences like healing, exorcism and reintegrating the marginalized. Although this new world still is not more than a tiny little seed (mikróteron, Mark 4:31) it is the new irresistible power which will overcome the old, sinful world order and create a new one dominating all (meĩzon pántōn, Mark 4:32). Those who believe in Jesus' basileia-preaching are people with a future. They already understand reality in the light of God's powerful change. They already feel, think and act according to his project of renewing all and everything. Switching the myth for the poor and suffering means they should no longer understand themselves as powerless victims and helpless losers. They are members of the new world which will completely change their position and put an end to their suffering. As this new world is beginning already now, the poor already now gain a new status and new value: they are no longer lost and forgotten; they are important as they have the supreme power of God and his world on their side.

\section{THE POTENTIAL SIGNIFICANCE TODAY}

As the message of Jesus' beatitudes is a religious one, it is clear that it doesn't mean anything to those who deny the importance of religion at all. Those who don't believe that the word "god" refers to any reality beyond language will of course not understand that it makes any sense to tell the poor that God is on their side. The problem of "new atheism"11 however seems to be very much a problem in Western Europe only. It is almost no problem in the Americas and it definitely is no major problem in Africa. Instead African reality can be seen as soaked by religion and the role of religion for the further development of African society can hardly be overestimated (cf. Gunda 2011).

When we ask for the significance of Jesus' beatitudes in the mission of Christian church today, the preaching of metánoia comes at first place.

11 The most popular example is Dawkins 2006. 
Church has to share in Jesus' switching the myth. While the present world order tends to define the poor as the powerless victims of irresistible globalization, church has to tell another story. The poor are not cursed, they are not the weak who deserve their status as they quite simply are not fit enough for the new deregulated capitalism. Like Jesus Christians have to connect God and the poor by their preaching. At the same time they have to promote the gap between God's will and the will of those who are rich and powerful. Disconnecting of God and the upper class is undoubtedly part of our mission, at least if we define this mission in the perspective of Jesus. Perspective is a very important word in this context as it makes clear that our mission has nothing to do with simply imitating Jesus or imitating biblical texts (cf. Hoffmann \& Eid 1976:15-25; Eid 2011). Instead of simply playing Jesus' role and repeating his words we have to analyze quite properly the situation.

This means not only to ask who the poor are today but also to describe our own place in the setting. We as academic theologians usually are not poor. Most of us have a decent salary and can afford to live quite a comfortable life. The beatitudes don't mean us; that's obvious. If we share in preaching the close connection between God and the poor we share also in stating that we - members of middle or upper class - are disconnected from God. As far as we are rich and powerful we are part of the old world which the power of God's basileía will overcome. ${ }^{12}$ If however we understand that our richness is part of a global system of sin, we are on the best way to solidarity with the suffering and to encounter God's salvation. ${ }^{13}$ This implies metánoia, new thinking. If God and the poor are connected then we have to understand that our status as rich people is that of sinners called to repentance. Richness is a challenge. It has to be shared and it urges to struggle for justice in economic and social structure. The ultimate aim of our acting must be the eradication of poverty as Dons Kritzinger (2012:17) rightly put it. Although the Kingdom of God, i.e. a perfect world without any suffering and even without death, remains exclusively

12 Luke quite well understood this aspect of the Jesus tradition. That is why he complements each makarism with a 'woe' (cf. Luke 6:24 ff) indicating the necessity of repentance. As he was writing for a Christian community which not consisted of poor people only he offered giving and sharing as the proper way for rich Christians: "make friends for yourselves by unrighteous mammon" (Luke 16:9). Those who were not ready to do so were told to beware of ultimate failure (cf. Luke 16:19-31).

13 That is exactly why Matthew transformed the beatitude to ", the poor in spirit" (Mat 5:3). Although God's blessing primarily is for those who are materially and mentally poor, solidarity can integrate those who are well off to the divine blessing also. In the spirit of Christ they can identify with the suffering and thus become spiritually poor by sharing and helping. 
God's work, we have to strive for a fair society in the global village with a kind of wealth which respects environmental necessities. If we do not share in this struggle we are not really part of God's chosen people. The call to metánoia is a call to decide, if we want to be basileia-people or if we want to belong to the obstacles which God has to overcome in taking control of his creation.

In a time where empowerment of the poor is a key concept for a new thinking in so many fields, especially in developing a human kind of economy (cf. Yunus \& Weber 2007) and more gender justice, Christians should not underestimate the value of spiritual empowerment of the poor. The United Nations' International Fund for Agricultural Development (IFAD) states:

\begin{abstract}
Poverty is a multi-faceted phenomenon, defined (and explained) as a situation in which a person lacks the necessary capabilities and entitlements to satisfy his or her basic needs and aspirations. From this point of view, the fight against poverty must consist in establishing entitlements that will allow the poor access to the material, social, and spiritual means to develop their capabilities. Thus, it becomes necessary to focus on empowerment of the poor as the crucial requirement for a sustainable solution to poverty and hunger. Empowerment is defined here as the ability of people, in particular the least privileged, to: (a) have access to productive resources that enable them to increase their earnings and obtain the goods and services they need; and (b) participate in the development process and the decisions that affect them. These two aspects are related; one without the other is not empowerment (IFAD [n.d.]).
\end{abstract}

It must be clear from this programmatic statement that the beatitudes can be understood as a specifically Christian facet of empowerment, namely a spiritual empowerment which contributes to self-confidence and self-esteem as central factors in striving for change. Especially in African societies which are known as dominated by religion the religious message of Jesus' beatitudes could be a most effective factor in empowering the poor. Jesus may not have been a revolutionary and not even a politician and his beatitudes not even are ethical commandments, but his myth switching message can have tremendous effects if thoroughly preached. The religious disenfranchisement of the global social and religious status quo marks the state of the global village as a state as sin, as something that must be changed and can be changed. And it invites all those honestly seeking God to look at the poor and their situation. Solidarity with the poor is coming closer to God as he bound himself to them. God promised to change their situation. Therefore those who are with the poor helping them 
to master their life and get things changed are close to God - partners in his work of recreating his world.

\section{FAREWELL TO THE “GOSPEL OF WELFARE”?}

Maybe my interpretation of Jesus' beatitudes will not have much chance to be accepted. It simply seems too far away from the "Gospel of Welfare" (also: "Prosperity Gospel" or "Gospel of Health and Wealth"), the most popular kind of preaching in many African and American churches. As an option for the poor doesn't help if it is not accepted by the poor themselves ${ }^{14}$ it is highly necessary to make the relation between the makarisms of Jesus ${ }^{15}$ and the most popular version of Christian preaching worldwide clear.

The perspective of Jesus' Gospel for the poor relates to the Prosperity Gospel in different ways. As I am neither an expert in African pastoral nor in the Prosperity Gospel movement, I will not try to deliver a detailed analysis or critique of the Prosperity Gospe ${ }^{16}$ and its effect on African Christianity. I will instead concentrate just on some points that seem important to me. In my eyes they are so central that they can and must be used to evaluate any type of Christian pastoral be it the multi-faceted phenomenon of Prosperity Gospel or the pastoral of traditional churches like Catholics, Anglicans or Lutherans.

1. The poor have a right to get out of their precarious situation.

2. Poverty has nothing to do with "lack of faith".

3. Richness is sin as long as it is not shared with the poor.

4. Individual change is not enough.

Ad 1: The Prosperity Gospel rightly stresses that poverty is something that has to be overcome. God is against poverty and his love towards humanity should show in a life without poverty. Jesus calls the poor happy not because they are poor but because God will put an end to their precarious situation. The dynamic drive from poverty to welfare is clearly something that Jesus and the Prosperity Gospel are sharing.

14 Cf. Gideon van der Watt's contribution in this Supplementum (p. 35-53).

15 Of course I only refer to my understanding of the Jesus tradition when I simply say Jesus in this last paragraph.

16 For a critical review of the Prosperity Gospel cf. for example Jones \& Woodbridge 2010. 
Ad 2: Preaching of Prosperity Gospel seems to turn away from Jesus when the poor are blamed for their own poverty by telling them that lack of faith is the reason for staying poor. Acknowledging the brutal dynamics of global capitalism producing more and more poverty every day it seems quite cynical to blame individuals for their poverty and define them as persons who just should have more faith. This kind of preaching is even more cynical if it is combined with the pressure to realize this faith in being member of a specific church or in paying to the church leaders who already are well off. If the Prosperity Gospel is transformed into a new way of exploiting the poor it certainly has not much to do with Jesus. His beatitude is not: Happy are the poor if they share my belief and pay my ministers. His makarism addresses the poor without any condition. It also goes to those of the poor who are with little faith or even with none at all.

Ad 3: In the perspective of Jesus and in the light of the further Christian tradition as documented in the canonical texts of the New Testament richness is nothing innocent. As long as poverty exists, wealth implies the duty of sharing. If the Prosperity Gospel is preached in a way which might foster an egoistic fight for bettering up the situation of an individuals only, it may be labelled as Christian. In reality, however, such a "serving Mammon" (Luke/Q 16:13) has nothing to do with Jesus and his message. Those who simply want to be rich without seeing the obligation to share with those in need are serving Mammon, the god of global capitalism, but they definitely are not serving the God of Abraham, Isaac, Jacob and Jesus. If the Prosperity Gospel is interpreted in this direction it is only a variation of capitalist money religion disguised as Christian faith.

Ad 4: Looking for the perspective of Jesus means also to realise that Christianity is no longer a tiny little minority as it was in the times of Roman Empire. While Jesus had no economic or political power at all, Christians nowadays have access to all institutional tools of economy governance and developmental politics - on national levels as well as on the global level. If we do not use this influence to reduce the "production" of poverty, our individual sharing and helping becomes rather cynical. Charity always is a Christian duty, but it is not enough. It has to be accompanied by the struggle for justice in economic and political structures. The Prosperity Gospel as well as traditional ways of preaching Jesus' gospel has to open for that dimension of eradication of poverty also.

To sum up I would say that the Prosperity Gospel should not be criticised in general as degeneration of Christian preaching, but of course those preaching the Prosperity Gospel always have to check their preaching for its accordance to the perspective of Jesus. This kind of permanent selfevangelisation is, however, necessary for all kinds of Christian preaching in all denominations. It is not confined to the Evangelicals or Pentecostals only. 


\section{BIBLIOGRAPHY}

Assmann, J.

1992. Das kulturelle Gedächtnis. Schrift, Erinnerung und politische frühen Hochkulturen. München: Beck.

Coluins, R.F.

1992. Beatitudes. In: D.N. Freedman (ed.), Anchor Bible Dictionary Vol 1. (York: Doubleday), pp. 629-631.

DAWKINS, R.

2006. The god delusion. London: Bantam Press.

EID, V.

2011. Praxis-Perspektiven aus der Bibel? Rückblick auf eine Theorie. In: J. Kügler et al. (ed.s). Bibel und Praxis (Berlin: Lit, bayreuther forum TrAnsit 11), pp. 37-43.

FREGE, G.

2008 [ 1891]. Funktion, Begriff, Bedeutung. Fünf logische Studien, $2^{\text {nd }}$ Edition, Göttingen: Vandenhoeck \& Ruprecht.

Gunda, M.R.

2011. Introduction. In: M.R. Gunda (ed.). From Text to Practice. The role of the Bible in daily living of African people today (Bamberg: UPB, Bible in Africa Studies 4) pp. 9-20. (Accessible online: http://www.opus-bayern.de/uni-bamberg/volltexte/ 2011/310/)

Hoffmann, P. \& Eid, V.

1976. Jesus von Nazareth und eine christliche Moral. $2^{\text {nd }}$ Edition. Freiburg: Herder. Quaestiones Disputatae 66.

International Fund for Agricultural Development (IFAD).

n.d. Empowerment of the Poor. [Online] Retrieved from: http://www.ifad.org/ events/past/hunger/empower.html [1 June 2011].

JEREMIAS, J.

1962. Die Gleichnisse Jesu. $6^{\text {th }}$ Edition. Göttingen: Vandenhoeck \& Ruprecht.

Jones, D.W. \& WoOdBridge, R.S

2010. Health, Wealth \& Happiness: Has the Prosperity Gospel Overshadowed the Gospel of Christ? Grand Rapids: Kregel Publications.

KRITZINGER, J.J.

2012. Poverty relief or poverty eradication. Acta Theologica Supplementum 16:17-34.

KÜGLER, J.

1997. Pharao und Christus? Religionsgeschichtliche Untersuchung zur Frage einer Verbindung zwischen altägyptischer Königstheologie und neutestamentlicher Christologie im Lukasevangelium. Bodenheim: Philo. Bonner Biblische Beiträge 113. 
2003. „Für wen haltet ihr mich?" - Neutestamentliche Christologien und ihre Relevanz für heutiges Christsein. Religionsunterricht an höheren Schulen 46:311-318.

2006. Das Reich Gottes auf den Dörfern. Ein bibeltheologischer Essay über die Politik der Pastoral Jesu. In: R. Bucher \& R. Krockauer (Eds.), Pastoral und Politik. Erkundungen eines unausweichlichen Auftrags (Münster: Lit, Werkstatt Theologie 7), pp. 5-21.

2007. Gottes Königsherrschaft als „Rahmenmythos“ der Pastoral Jesu. In: R. Bucher \& R. Krockauer (Eds.), Gott. Eine pastoraltheologische Annäherung (Münster: Lit, Werkstatt Theologie 10), pp. 11-38.

MeIER, J.P.

1994. A Marginal Jew. Rethinking the Historical Jesus Vol 2. Mentor, Message, and Miracles. New York: Doubleday.

Robinson, J.M., Hoffmann, P. \& Kloppenborg, J.S. (Eds).

2000. The critical edition of Q. Synopsis including the Gospels of Matthew and Luke, Mark and Thomas with English, German, and French translations of $Q$ and Thomas. Leuven: Peeters.

SANDER, H.-J.

2005. Die kritische Autorität der Exegese für die Dogmatik. In: U. Busse (ed.), Die Bedeutung der Exegese für Theologie und Kirche, (Freiburg i.Br.: Herder, Quaestiones Disputatae 215), pp. 38-75.

TheISSEN, G.

2000. Die Religion der ersten Christen. Eine Theorie des Urchristentums. Gütersloh: Kaiser.

ToBIN, T.H.

1992. Logos. In: D.N. Freedman (ed.), Anchor Bible Dictionary Vol 4. (New York: Doubleday), pp. 348-356.

VAN DER WATt, G.

2012. “... but the poor opted for the Evangelicals!" - Evangelicals, poverty and prosperity. Acta Theologica Supplementum 16:35-53.

Yunus, M. \& Weber, K.

2007. Creating a world without poverty. Social business and the future of capitalism. New York: Public Affairs.

Keywords

Beatitude of the poor

Gospel

Poor
Sleutelwoorde

Saligspreking oor die armes

Evangelie

Armmoede 